\title{
MILLBANK FROM MEDIEVAL TIMES TO THE PRESENT
}

\author{
DR. N. R. H. BURGESS, B.Sc., Ph.D., F.R.E.S., M.I.Biol. \\ Royal Army Medical College, Millbank
}

With the closure of The Queen Alexandra Military Hospital another page in the history of Millbank is turned and the hospital takes its place among other famous buildings which have stood or still stand in its neighbourhood.

The hospital was constructed between 1903 and 1905, and was opened by HM King Edward VII on 1 July 1905. The area of London's Thames-side on which it was built has passed through a strange and fascinating evolution. Its early development is closely linked with the presence from about $1050 \mathrm{AD}$ of the Abbey foundation at Westminster, on the site still occupied by the great parish church of St. Peter. This abbey was built on a slightly raised triangle of land surrounded on one side by the Thames itself and on the other two sides by the branch. ing of Tyburn Brook flowing into the river (Map 1). The site was known as Thorney Island, due to the tangled undergrowth covering it; the name is remembered to this day in Thorney Street, near Lambeth Bridge. The whole area was marshy, uninhabited and liable to flooding. The monks built a water-mill on the river's edge and banked the river to give a better flow, though the mill itself may have been driven by the southern branch of the Tyburn rather than by the Thames itself. The mill stood where now Great College Street meets Abingdon Street and has given the name Millbank to the road which runs between Lambeth Bridge and Vauxhall Bridge.

The Tyburn in 1236 flowed from the north to cross the Military Way (Oxford Street) at what is now Marble Arch. Water was taken from there to the City of London to the east, and the Brook continued south towards the Thames. The monks of Westminster drew their water from the Hyde Park area since it was too stagnant once it reached the marshy river's edge. Near what is now Buckingham Palace the Brook branched and gave off a small stream which flowed due south and was known as the Old Ditch. It flowed through Bulinga Fen (the Military Hospital stood in Bulinga Street) to reach the Thames at Merflete at a point near the present Chelsea Bridge. The stream was later called Tachbrook, a name recalled by estates, schools and Tachbrook Street itself, which closely follows the original line of the Brook. It flowed through the present site of the Churchill Gardens Comprehensive School and reached the Thames in Churchill Gardens. It was later diverted to supply the Chelsea Water Works on a site occupied by the Victoria Station railway complex. The King's Scholars Pond sewer now contains these streams.

John Stow, writing in 1598 says of the area "the Millbanke is a very long place, which beginneth by Lindsay House or rather by the Palace Yard, and runneth up to Peterborough House which is the farthest house. The part from against the College Street unto Horse Ferry hath a good row of buildings on the east 


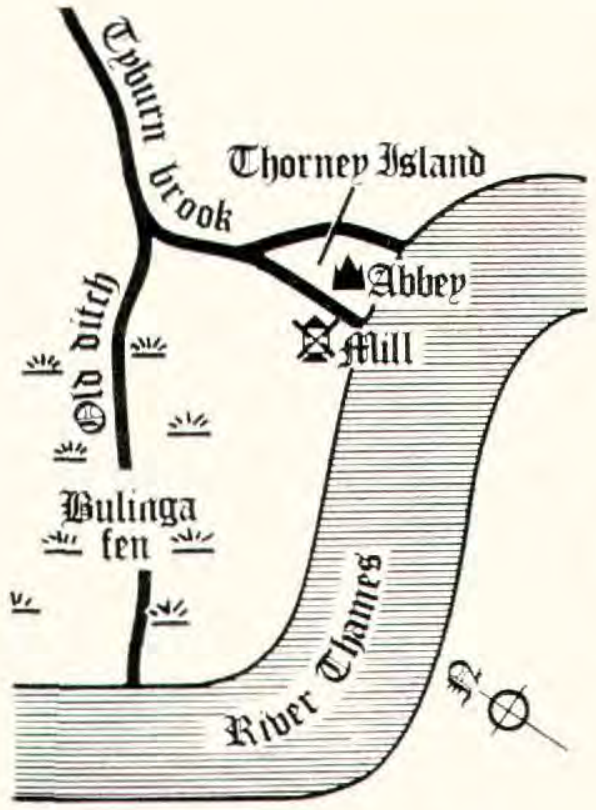

Map 1. The area about 1066

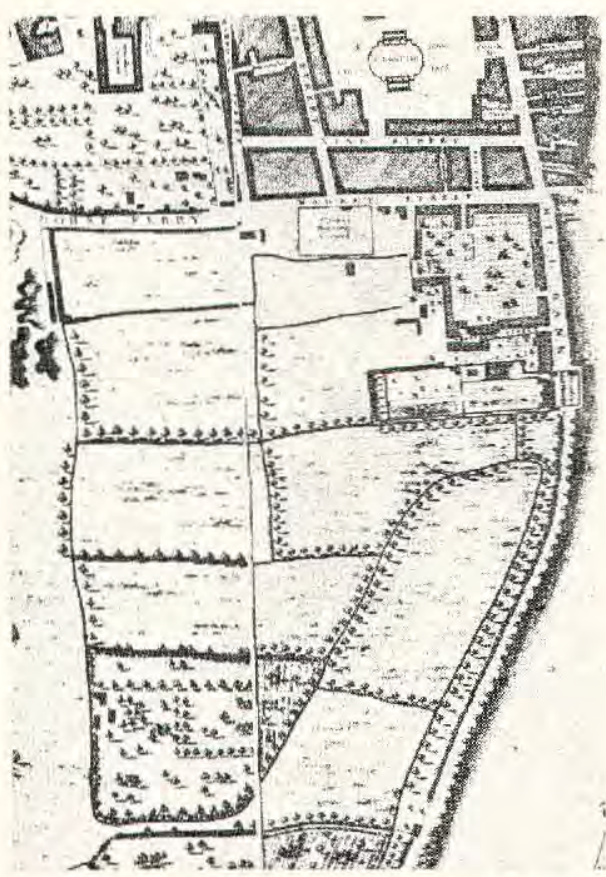

Map 3. From Rocque's Plan of the Cities of London and Westminster 1746.

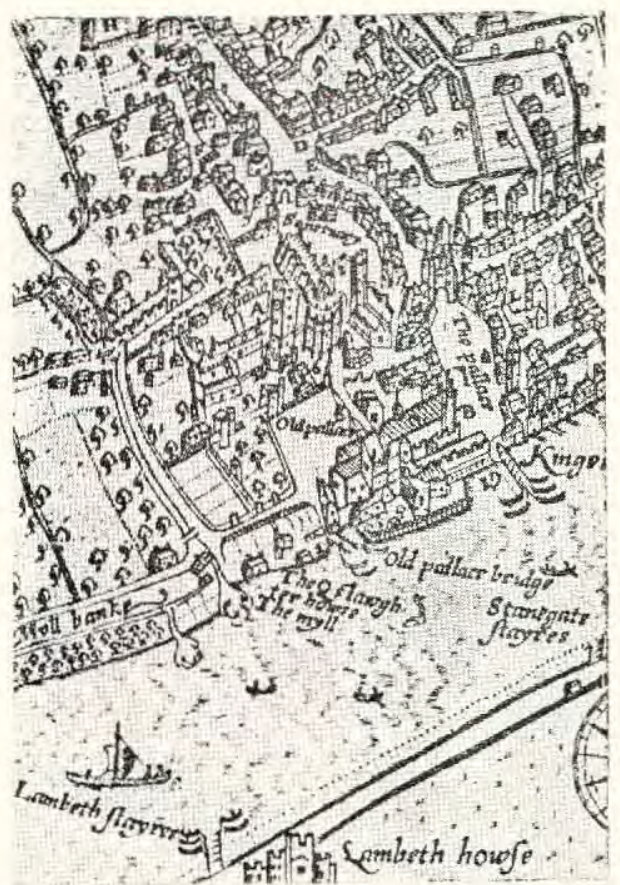

Map 2. From Norden's Map of Westminster 1593.

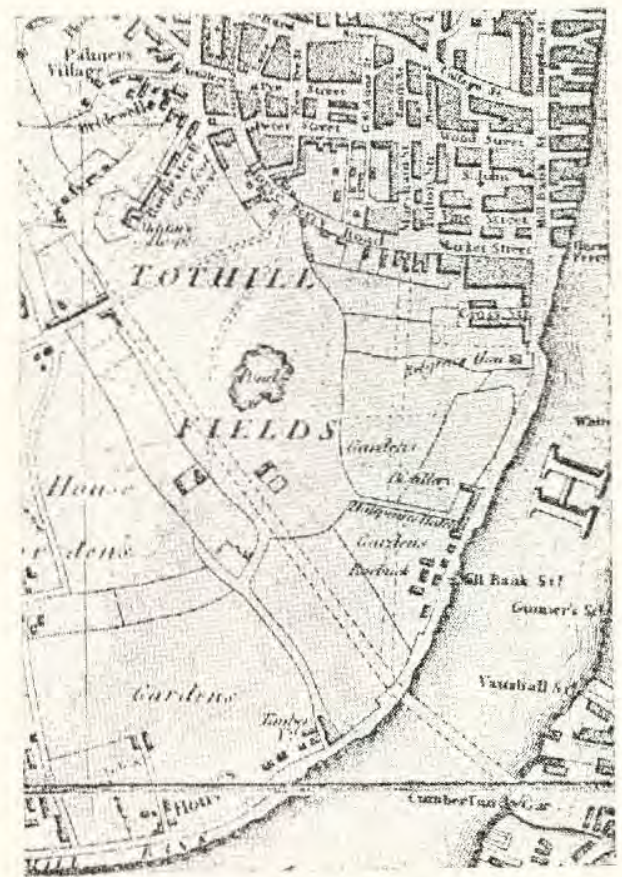

Map 4. From Lauric and Whittle's New Map of London 1809. 
side next to the Thames which is mostly taken up with large woodmongers' yards and brewhouses, and there is a water-house which serveth this side of town. The north side is but ordinary, except one or two houses by the end of College Street, and that part beyond the Horse Ferry hath a good row of houses much inhabited by the gentry, by reason of the pleasant situation and prospect of the Thames. The Earl of Peterborough's house hath a large courtyard before it and a fine garden behind it, but its situation is but bleak in winter and not over healthful, as being so near the low meadows on the south and west parts". ${ }^{1}$ Norden's Map of Westminster (Map 2) shows the area in 1593.

By 1746 when John Rocque published his "Plan of the Cities of London and Westminster" (Map 3), the area to the north of the Horse Ferry had become substantially built upon. Just to the south, Millbank continued as in Stow's description, to a large estate, here called Grosvenor House. Still further south were river meadows, market gardens and the open marshy area of Tothill Fields. To the north of the "Road to the Horse Ferry" which continued to the river along Market Street, are Marsham Street, Tufton Street, Vine Street and the church of St. John the Evangelist, Queen Anne's "footstool church", built in 1728. The Burying Ground on the south side of Market Street was the graveyard of St. John's Church. Even today it is holy ground, and exists as an ornamental garden between the Westminster Hospital and the Medical School, with a few old graves along its edges.

By the end of the century development had begun along the south side of Horse Ferry Road. Grosvenor House had become Belgrave House, and along Millbank was the Roebuck Inn and a distillery owned by a Mr. Hodge ${ }^{2}$. Tothill Fields was said to "support snipe in the bogs and quagmires; and hospitals, bridewells, almshouses and pest houses"'.

Laurie and Whittle's "New Map of London" (Map 4) shows the appearance of the area in 1809. This period was the beginning of the Industrial Revolution, a time of considerable expansion in house building, and the development mania is evident on this map from the suggested routes dotted on it. From Vauxhall Bridge a road was planned towards Chelsea Road in the north-west and another towards the north to meet Horse Ferry Road. In-filling of houses to the north was almost complete and development was beginning to the north of Tothill Fields.

In 1799 the Millbank Estate of about 53 acres was purchased from the Marquis of Salisbury for the erection of a Penitentiary under the Act 34 Geo. 3, Cap. 84. By a subsequent Act of 1812 it was provided that the land should vest absolutely in His Majesty, His Heirs and Successors, for the use of the public and the purposes of the Act. This Crown ownership has had a considerable affect on the evolution of the area to its present form. In 1813 work began on the building of the Millbank Penitentiary which was completed in 1821 (Fig. 1). Built in a hexagonal star shape with the Governor's house in the centre, it contained over $1,000$ cells linked by three miles of corridors, and could house 800 male and 400$)$ female prisoners. It became the embarkation point for many sentenced convicts on their way to the new penal colonies in Australia; boats tied up at the river steps to take their passengers to larger craft anchored in the Thames estuary. The original riverside bollards to which the boats were tied are now in the Mc- 
Grigor Courtyard of the RAMC Headquarter Mess. The prison covered 16 acres, less than one third of the total estate bought from the Marquis of Salisbury. The Crown Lands Act of 1845 provided that the remaining two thirds should be placed under the management of the Commissioners of Woods (later Commissioners of Crown Lands, now Crown Estate Commissioners) and be let on building leases. This initiated the "urbanisation" of the area.

Pigot and Company's New Plan of London (Map 5) "taken with the best authorities with geographical bearings from the dome of St. Paul's" shows the area in 1823. The original Vauxhall Bridge, known as Regent Bridge, was started in 1813 and completed in 1916 at a cost of $£ 300,000$ (Fig. 1). It consisted of 9

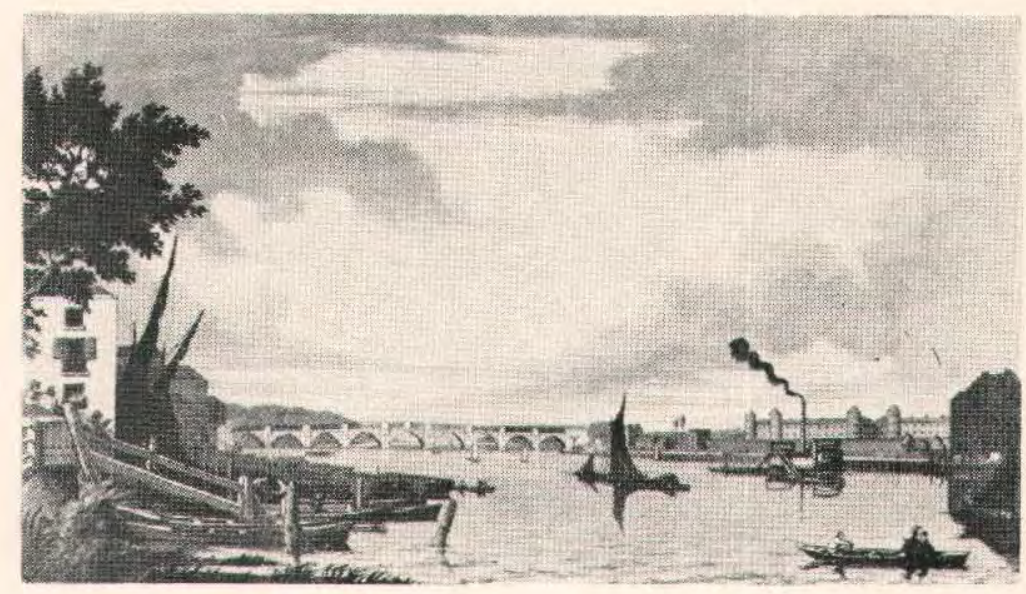

Fig. 1. View behind the barge on the right of the Millbank Penitentiary and left of centre of the new Vauxhall Bridge.

arches each of 78 feet span with a roadway width of 36 feet; the total length was 950 feet with a landing pier half-way across. The Royal Clarence Bridge, now Lambeth Bridge, was planned in this period but was not built until some 100 years later. The map shows considerable development over Tothill Fields. Vincent Square, "a playground for the Westminster Scholars" and still playing-fields for Westminster School, is in existence, as are Regent Street, now Regency Street, New Road, now Vauxhall Bridge Road, and a number of smaller streets in the area.

During the first half of the 19th century a large part of the area was developed into housing estates of squares and terraced houses faced with white stucco, erected by Thomas Cubitt Ltd., one of the "better speculative builders"3. His works provide an interesting architectural link between Georgian and Victorian London, much of which still exists in Bessborough Gardens, Ponsonby Terrace, and Ponsonby Place. "Large, new, comfortable middle-class houses were built between Westminster and Chelsea, where a wide, flat and windy space had always existed. Here boys from Westminster School had hunted wild fowl on autumn afternoons, and right up to the 19th century, foot-pads had molested late travellers when nights were dark" ${ }^{\text {. }}$. By 1826 New Road became a thorough-fare along the river from Vauxhall Bridge to Millbank Row. Grosvenor Wharf was built on the site of Grosvenor House, and there was a prominent ditch around 
the Penitentiary. Mr. Copeland's yard stood between Page Street and Horse Ferry Road and there was a button factory in Regent Street. In 1834 the Old Houses of Parliament were burnt down. Rebuilding began in 1837, but was not completed until 1860. By 1836 a gas-works had appeared between Vauxhall Bridge Road and Scholars' Pond to the south, and a turnpike was functioning at the end of the bridge.

The London Post Office Map of 1861 (Map 6) shows the development of Cubitt's estates. Housing had spread to the walls of the penitentiary; the railway had come to Victoria to the north and Waterloo on the south side of the river. Trinity Church in Bessborough Gardens is shown for the first time.

Stanford's Library Map of London and its Suburbs (Map 7) shows the area in 1891. The Penitentiary was in fact closed down in 1890, but had not been demolished. Of interest are the gasometers of the Chartered Gas Company, extensive wharfing on either side of Vauxhall Bridge, and a number of light industries such as Horn's Engine Works and Mowlem \& Company's Stone Yard, north of the prison. Millbank is called Grosvenor Road which continues towards Chelsea. King's Scholars Pond Sewer and a small-arms repairing works are shown to the south-west of Trinity Church, and the Army Clothing Depot can be seen on the present day site of Dolphin Square. Lieutenant-Colonel A. Martin Leake, V.C. and Bar was in charge of the Clothing Depot in the 1930s. Roehampton Street, now John Islip Street, only went as far as Ponsonby Place, and trams ran up Vauxhall Bridge Road, with a depot where now there is a garage and car showroom.

By 1897 the National Gallery of British Art, the Tate Gallery, had been completed and presented to the Nation by Sir Henry Tate, the sugar millionaire. The County of London Map of 1903 (Map 8), published to show "premises licensed for the sale of intoxicating liquors", shows the present plan of roads in the Millbank area. A gap has been made in Ponsonby Place through which John Islip Street passes; this is very apparent in the present appearance of the houses. An "Off-Licence", still in existence, is shown at the junction of Ponsonby Terrace and Roehampton Street, and "victuallers" are shown in several places in the neighbourhood; the only one to remain in the same position to this day is the Morpeth Arms, on the corner of Ponsonby Place and Grosvenor Road (Millbank).

The public house shown on the south corner of Wheeler Street is now a barber's shop, retaining the old exterior, and opposite it is the White Swan, not shown at this date.

In 1903 barracks were built on the Crown land south of the Tate Gallery and in 1907 the Royal Army Medical College and Headquarter Mess were completed. In the meantime The Queen Alexandra Military Hospital had been built and opened in 1905. The hospital was originally intended to replace the three regimental hospitals of the Brigade of Guards, situated in Vauxhall Bridge Road, Warwick Way and Rochester Row. However its scope was increased as a result of the South African War, and successive World Wars further extended its role. It became the central reference hospital for the Army and had links, through its honorary consultant staff, with most of the major London teaching hospitals. It had its own school of nursing for potential State Registered Nurses and a number of medical appointments in the hospital were recognised by the Royal Colleges 


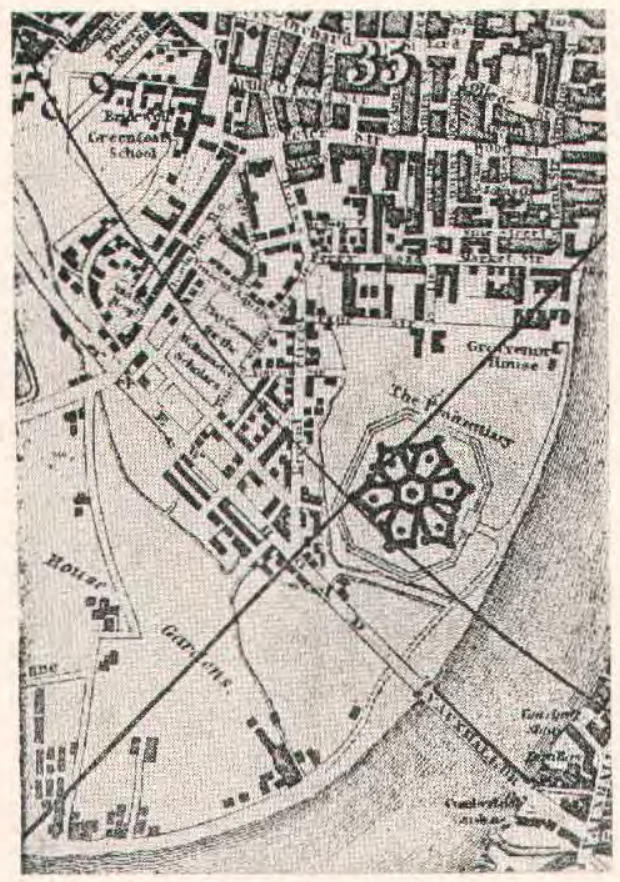

Map 5. From Pigot \& Company's New Plan of London 1823.

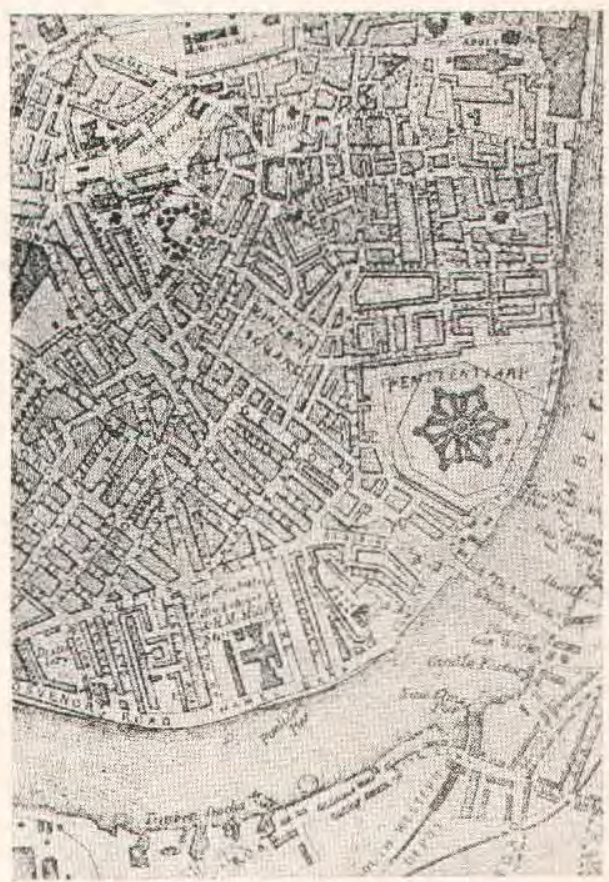

Map 6. From the London Post Office Map 1861.

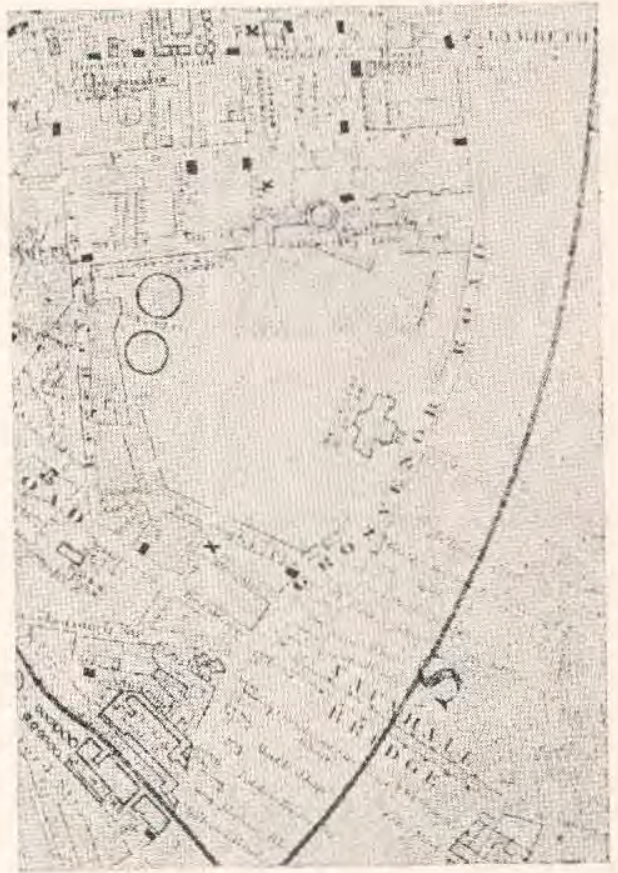

Map 8. From the County of London Map 1903.

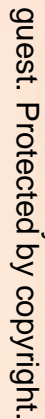


as training posts for higher medical qualifications. Three hospital wards bore the names of King Edward, Princess Victoria and Queen Alexandra, and others were named after Army medical officers who gained distinction, Allen, Babtie, Barry, Chavasse, Douglas, Mouatt and Martin-Leake. An interesting account of the hospital chapel is given by Duffy ${ }^{4}$. The out-patient department was opened by HRH The Prince of Wales on 26th November 1929. In June 1940 the day-rooms of Chavasse and Queen Alexandra wards, on the ends of two front wings of the hospital, were destroyed by enemy bombing. They were rebuilt in the original style with the damage undetectable.

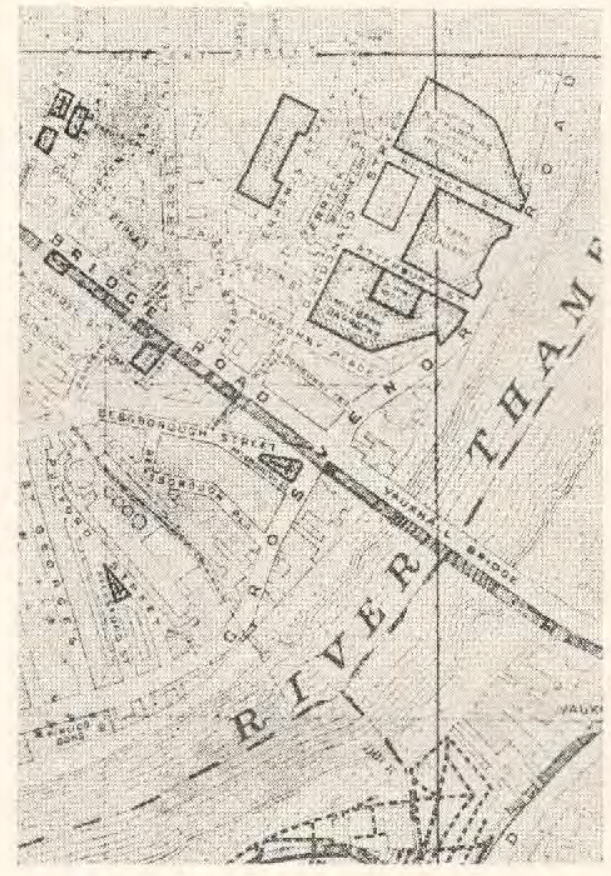

Map 9. From London County Council Map 1913.

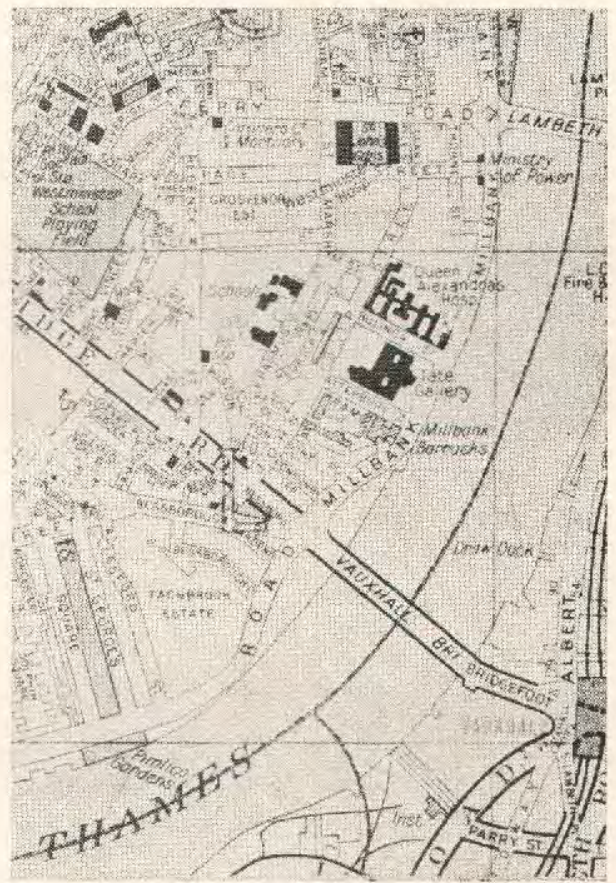

Map 10. From Geographia Map 1965.

In the period after the 1914-18 War considerable Council development of five and six-storey blocks of flats took place in the area north-west of Dundonald Street, now John Islip Street (Map 9). Much of this estate belongs to the Peabody Trust. The gasometers shown on the map were not removed until 1966. Thomas House and ICI House by Lambeth Bridge were built about 1928 and the land on either side of St. John's burial ground was bought in 1933 for the new Westminster Hospital and Medical School, opened in 1938. Between Thames House and the Queen Alexandra Military Hospital stood a jumble of dwellings, warehouses, stables and yards. Some of these were demolished in the early 1960's to make way for the Millbank Tower complex which includes a 34 -storey 387 feet high skyscraper, and lower-level blocks of offices and flats with car-parking facilities and gardens ${ }^{5}$. 
Plans for the traffic development of Vauxhall Bridge have been numerous in the last 20 years. Millbank from Lambeth Bridge to the RAMC Headquarter Mess was widened and the river walls rebuilt in 1966. The walls had been strengthened in 1930 after the disastrous flooding of 1927 when inhabitants sleeping in the basements of Ponsonby Terrace and other riverside streets had been drowned in their beds. Over 60 people in all died when the river overflowed its banks at 4 o'clock that morning. An amusing story is told of six patients from the Military Hospital who had been discharged just before the flooding but not removed from the patients' list. Many hours were spent by anxious officials searching for them until it was realised what had happened!

The widening of Millbank was completed in 1969 (Map 10). Until 1966 a variety of buildings stood in the triangle on the corner of Vauxhall Bridge and Millbank, among them a 'nappy service' laundry ominously near the river's edge, and the offices and yard of Holloway Brothers, the builders. A modern office block occupied by the Foreign Office has now been built, taking up only part of the space, the rest of which is a pleasant garden, with lawns and a fountain. The water-cooling tower for the air conditioning of the Foreign Office block stands beside the road and is an interesting example of modern, functional sculpture, contrasting startlingly with the Henry Moore bronze nearer the Tate Gallery. At the other side of the bridge-foot, Imperial House, occupied for many years by the offices and flour mills of Hovis Limited, was demolished in 1968 and new premises built on the site. There are a few remaining wharves on this bank of the river but all are obsolete and it is planned to close them in the near future to make way for further widening of the road. As long ago as 1943, in the County of London Plan, it was pointed out that this industrial oasis in an amenity area was out of keeping and should be removed; over thirty years later this has still not been completed.

Trinity Church in Bessborough Gardens was destroyed by enemy bombing in 1943 and remained derelict until 1963 when the site was cleared and the traffic flow reorganised round the square. Trees and grass were planted, only to be rudely disturbed three years later when work began on the new Victoria Line Underground. The square was used as a point for the removal of tunnelling waste, and buildings and pumps, cranes and other equipment were installed. A site was also cleared further up Vauxhall Bridge Road at Rampayne Street for the new Pimlico Underground Station which was opened in 1971. The houses surrounding Bessborough Gardens and those in Ponsonby Terrace, Ponsonby Place and part of John Islip Street, are the ones originally built by Thomas Cubitt in the early 1830 s.

Vauxhall Bridge, completed in 1816, was demolished in 1904 and a temporary foot-bridge built across the Thames opposite the Tate Gallery. The new Vauxhall Bridge was opened in 1906. It is of 5 spans and is $760 \mathrm{ft}$. long; the old bridge was $950 \mathrm{ft}$. long which gives some indication of the reclamation of the river bank during this period. The carriageway was $50 \mathrm{ft}$. with $15 \mathrm{ft}$. footways on either side (Fig. 2). During 1973-75 the bridge was widened to take six lanes of traffic at the expense of the footways. Lambeth Bridge was opened in 1932 during the period of development of Thames House and ICI House. This replaced the bridge opened in 


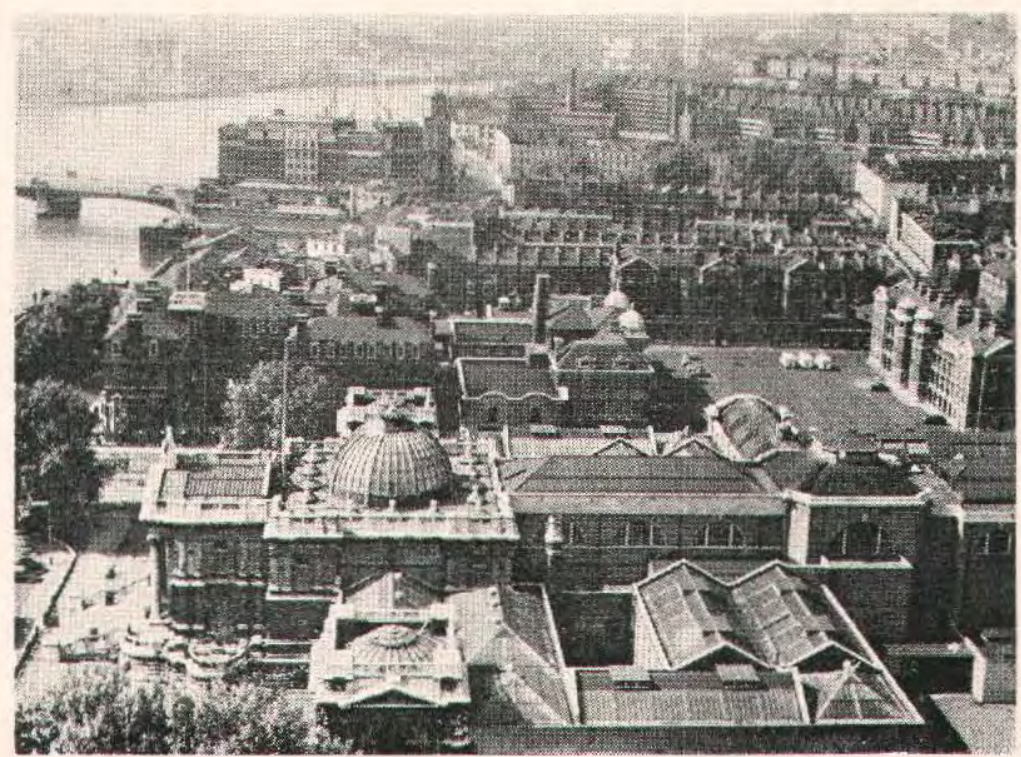

Fig. 2. View to the south showing the new Vauxhall Bridge, Royal Army Medical College and the Tate Gallery.

Taken from Millbank Tower in 1963.

1862. It consists of 5 spans and is 776 feet long. The carriageway is $36 \mathrm{ft}$. with $12 \mathrm{ft}$. footways on either side. In 1910 the fare from Millbank to Victoria by horse tram was $\frac{1}{2} \mathrm{~d}$. In Ponsonby Terrace is a green-grocer and an "Off-Licence". Opposite these stood a tailor's shop and a general store, until they were demolished in 1964 . A corrugated-iron fence still hides a derelict site. A branch of the Westminster Library survived next door until 1975.

Restricted parking came into force in November 1968 and meters sprouted from the pavements, adding to the forest of street lamps, traffic lights and road signs and the variegated colours on the road itself. The wider streets still have trees and the public gardens in the area are well tended.

The Queen Alexandra Military Hospital closed on March 11977 and the staff, patients and facilities are now based at the new Queen Elizabeth Military Hospital in Woolwich. Originally the plan was for the Tate Gallery ${ }^{6}$ to take over the site, on which a new Gallery building would be erected. However that idea has been shelved for an indefinite period and it is now proposed that at least part of the existing hospital buildings will be used for the display of some part of the collection or for working departments of the Gallery.

Thus the spirits of Army doctors and nurses, soldiers and patients join those of mediaeval watermen and grouse-shooters, Victorian prison-warders and convicts, and the many others whose presence has contributed to the long and fascinating history of Millbank.

\section{REFERENCES}

1. Stow, John (1603). 'A Survey of London'.

2. Knight, C. (1851). Ed. 'Cyclopedia of London'. Charles Knight, London.

3. GrIFFITHS, A. (1884). 'Memorial of Millbank'. Chapman \& Hall, London.

4. DuFFY, P. F. (1963). Hospital Scrapbook held in COs Office.

5. Catterick, P. J. (1961). J. roy Army med Cps. 407, 108-11.

6. TATE GalleRy Information SeRvices (1976) (personal correspondence). 